\title{
PRACE KONSERWATORSKIE I BADANIA ARCHITEKTONICZNE KLAUZURY DAWNEGO OPACTWA CYSTERSKIEGO W KRZESZOWIE PO DRUGIEJ WOJNIE ŚWIATOWEJ
}

Jest coś magicznego w dawnym cysterskim opactwie w Krzeszowie, które zintegrowane z przyrodą i krajobrazem urzeka skalą i dostojeństwem budowli konwentualnych, zachwyca grą światłocienia i wyrafinowaną plastycznością pełną harmonii oraz umiaru (il. I). Wspomniane cechy formalne architektury opactwa są od wielu lat przedmiotem uwagi konserwatorów, których celem jest zachowanie w jak najlepszym stanie substancji autentycznej. Zwłaszcza prace prowadzone po drugiej wojnie światowej są odzwierciedleniem powrotu do stanu z czasów budowy opactwa. Przez wiele lat powojennych głównym tematem zainteresowań były kościoły klasztorne opactwa krzeszowskiego, obecnie uwagę przykuwa konserwacja budynku klauzury oraz prace porządkujące teren, podczas których ujawniły się nieznane dotychczas relikty architektoniczne. Te właśnie zagadnienia stały się przedmiotem przedstawionych niżej rozważań - prezentowana praca jest częścią projektu badawczego realizowanego przez autorki w latach 20I4-20I8 ${ }^{\text {I }}$.

Zespół budynków dawnego klasztoru nadal dominuje nad zabudową wsi położonej w dolinie rzeczki Zadrny, dopływu Bobru. W centrum obwiedzionego murem terenu klasztornego znajduje się przestronny dziedziniec, na który prowadzi droga przechodząca przez bramę umieszczoną na zachodzie. Na północ od bramy zlokalizowana jest stara wozownia funkcjonująca obecnie jako Dom Pielgrzyma, na zachód od niego stoi kościół św. Józefa i obok dawny dom opata, obecnie Centrum Dialogu. Zdecydowaną dominantą zespołu jest okazały dawny kościół klasztorny pod wezwaniem Wniebowzięcia Najśw. Panny Marii z umieszczoną na wschodzie kaplicą św. Marii Magdaleny i Mauzoleum Piastów Świdnickich. Do świątyni od południa przylega dwuskrzydłowy budynek klauzury, którego jak wspomniano, powojenna konserwacja i prace architektoniczne zostaną poniżej omówione bardziej szczegółowo.

\footnotetext{
* Ewa Łużyniecka, profesor zwyczajny Wydziału Architektury Politechniki Wrocławskiej, zajmuje się historią architektury, projektowaniem konserwatorskim i kształceniem młodej kadry naukowej. Email: ewa.luzyniecka@ pwr.edu.pl.

Monika Dąbkowska, doktor nauk o sztuce, zabytkoznawca architektury sakralnej, absolwentka Uniwersytetu Mikołaja Kopernika w Toruniu. E-mail: cesta@abs.umk.pl.

1 Projekt badawczy pt. Badania przekształceń konserwatorskich $w$ architekturze opactw cysterskich na Ślasku przy zastosowaniu nowoczesnych technologii cyfrowych realizowany jest ze środków Narodowego Programu Rozwoju Humanistyki.
} 


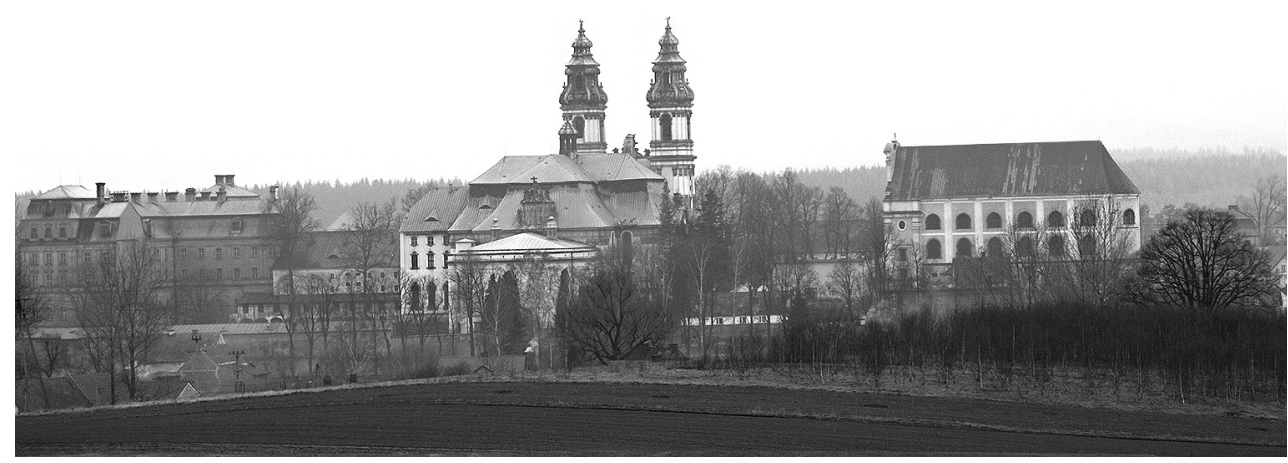

Il. I. Widok opactwa krzeszowskiego od wschodu, 2007, fot. E. Łużniecka

Architektura opactwa krzeszowskiego jest przedmiotem zainteresowania od wielu lat, w zasadzie nie ma opracowania mówiącego o barokowej architekturze śląskiej, w którym nie wspominano by o Krzeszowie ${ }^{2}$. Spośród wielu opracowań architektonicznych na uwagę zasługują prace Henryka Dziurli³ ${ }^{3}$ wieloletniego badacza i konserwatora, który zajmował się tym opactwem ponad pół wieku. Pod jego kierunkiem powstało szereg opracowań przygotowywanych w obecnie nieistniejącym wrocławskim oddziale Państwowego Przedsiębiorstwa Pracownie Konserwacji Zabytków ${ }^{4}$ - m.in. inwentaryzacje rzutów i elewacji. Prace wspomnianego autora były punktem wyjściowym współczesnych wydawnictw katalogowych ${ }^{5}$.

Założenie klasztoru cysterskiego w Krzeszowie ${ }^{6}$ wiąże się z osobą księcia świdnickiego Bolka I zwanego Surowym, syna Bolesława Rogatki i wnuka księżnej Anny, która po śmierci swego męża Henryka II Pobożnego postanowiła uczynić Kościołowi darowiznę i w I242 roku przekazała czeskim benedyktynom teren Gressebor. Benedyktyni odsprzedali w I289 roku wspomnianą darowiznę księciu Bolkowi I, a ten w I29I r. postanowił przeznaczyć ją na siedzibę cystersów. Konwent został sprowadzony w I292 r. z pobliskiego klasztoru henrykowskiego i w tym samym roku został także wystawiony dokument fundacyjny dla klasztoru potwierdzający hojną darowiznę. W późniejszych odpisach tego dokumentu z lat I299 i I3I8 znalazły się informacje o poświęceniu w I292 r. kościoła konwentualnego z ołtarzem głównym. W dokumentach nie ma natomiast informacji o średniowiecznym budynku klauzury.

\footnotetext{
2 Literatura przedmiotu zob. K. Kalinowski, Architektura doby baroku na Śląsku, Warszawa 1977, s. 83-86, 324326.

3 Należy tu zwłaszcza wspomnieć prace: H. Dziurla, Krzeszów, Wrocław-Warszawa-Kraków 1964; idem, Die Grüssauer Klosterkirche und das Piastenmausoleum - Zur Baumeister frage, „Zeitschrift des Deutschen Vereins für Kunstwissenschaft", 1974, t. 27, z. 1/4, s. 54-82; idem, Wertykalizm i tożsamość barokowej architektury Krzeszowa, w: Krzeszów uświęcony łaska, red. H. Dziurla, K. Bobowski, Wrocław 1997, s. 236-257; idem, Dzieje Krzeszowa, w: H. Dziurla, I. Kořán, J. Wrabec, Krzeszów, europejska perła baroku (Grüssau, die europäische Barockperle), red. A. Jarosiewicz, B. Skoczylas-Stadnik, Legnica 2001, s. 8-17.

4 Szczególnie należy wymienić: H. Dziurla, Krzeszów. Studium historyczno-architektoniczne, Wrocław 1961 (mps, Regionalny Ośrodek Dokumentacji Zabytków we Wrocławiu - dalej RODZW); idem, Studium historyczno-architektoniczne zespotu pocysterskiego w Henrykowie, Wrocław 1965 (mps, RODZW).

5 J. Pilch, Leksykon zabytków Dolnego Śląska, Warszawa 2005, s. 167; R. M. Sołdek, Szlak cysterski na Dolnym Śląsku, Wrocław 2007, s. 117-140; K. K. Czapliński, Klasztory i opactwa w Polsce, Katowice 2009, s. 74-79.

6 Na temat historii opactwa: rozdział Krzeszów, w: Monasticon Cisterciense Poloniae, red. A. M. Wyrwa, J. Strzelczyk, K. Kaczmarek, Poznań 1999, s. 165-173.
} 
Pierwsze źródła pisane dotyczące klauzury krzeszowskiej pochodzą z drugiej połowy XVII w. Po zniszczeniach związanych z wojną trzydziestoletnią i najazdem szwedzkim w Krzeszowie rozpoczęto przebudowę zarówno kościoła jak i budynków konwentu. W latach I677-I684 przebudowano klauzurę pod kierunkiem budowniczego Marcina Schupperta, a następnie Martina Urbana. Ponad sto lat później, po budowie nowego barokowego kościoła w latach, I727-I735 rozpoczęto po raz kolejny przekształcenia pod kierunkiem Antoniego J. Jentscha, lecz wybuch wojny i zajęcie Śląska przez Prusy przerwały te prace na długie lata. Dopiero w I774 r. podjęto następną próbę budowy nowego claustrum według projektu Johanna Georga Fellera, który zamierzał wybudować ogromne założenie z dwoma dziedzińcami. Nowe skrzydło południowe powstało do I782 r. W latach I788-I792, pod kierunkiem Jana Jerzego Rudolfa z Opola, wzniesiono, już w uproszczonej formie, łącznik wschodni. Na tym prace przerwano i klauzura już nigdy nie uzyskała zaplanowanej formy.

Sekularyzacja klasztoru nastąpiła w I8Io r. W jej wyniku kościół klasztorny stał się parafialnym, w budynku klauzury utworzono szkołę świecką, a w domu gościnnym siedzibę leśnictwa. Z powodu niemożności zagospodarowania starego budynku klauzury, w I873 r. podjęto decyzję o wyburzeniu go $^{7}$. W roku I9I9 opustoszały klasztor został przejęty przez wysiedlonych z Pragi benedyktynów z klasztoru Emauskiego. Papież Pius XI podniósł konwent w I924 r. do rangi opactwa, dzięki czemu możliwe były pewne działania budowlane, np. W I932 r. przy wschodniej elewacji gotyckiego skrzydła klasztornego, łączącej barokowe skrzydło z kościołem, dobudowano dwukondygnacyjny korytarz zewnętrzny. W roku 1940 klasztor przejęły władze III Rzeszy. Benedyktyni zostali zmuszeni do opuszczenia klasztoru $^{8}$. Część z nich powołano do wojska, czternastu zginęło na wojnie. Pozostali zajęli jedynie trzy pomieszczenia przy zakrystii. W klauzurze umieszczono początkowo obóz dla przesiedleńców, później dla Żydów ze Śląska, internowanych mieszkańców Lotaryngii i Alzacji. Pod koniec wojny ukryto w opactwie zbiory Biblioteki Pruskiej z Berlina. Ocalałe archiwalia po II wojnie zdeponowano w Bibliotece Jagiellońskiej.

W 1945 r. obóz ewakuowano i dawny klasztor przejęły władze polskie. Rok później ostatni zakonnicy posiadający obywatelstwo niemieckie opuścili Krzeszów, a na ich miejsce sprowadzono żeński konwent benedyktynek ze Lwowa, jedynie ojciec Bruno Studeny, z pochodzenia Czech, pozostał w opactwie aż do swojej śmierci jako kapelan benedyktynek. Siostry zamieszkały w prawie całym budynku klauzury, część zachodnia skrzydła południowego została przeznaczona na siedzibę duszpasterzy związanych z parafią krzeszowską. Duszpasterzami parafii w latach I946-I96o byli benedyktyni z Tyńca, w latach I960-70 księża diecezjalni ${ }^{9}$ i od 1970 do 2006 cystersi z opactwa w Wąchocku. W 2006 r., po wyborze krzeszowskiego proboszcza Eugeniusza Augustyna na opata Wąchocka, generał zakonu cystersów przekazał parafię krzeszowską diecezji legnickiej. Od tego czasu parafią zarządzają księża diecezjalni: ks. Włodzimierz Gucwa, a od 2008 r. ks. prałat Marian Kopko ${ }^{\text {Io }}$.

\footnotetext{
Zabytki sztuki w Polsce. Śląsk, red. S. Brzezicki, Ch. Nielsen, G. Grajewski, D. Popp, Warszawa 2006, s. 456.

B. Ziętara i in. Krzeszów uświęcony łaska, Wrocław 1997.

H. Dziurla, Dzieje Krzeszowa, op. cit., s. 9.

10 R. Werszler, Architektura wnętrza i umeblowanie biblioteki opactwa cystersów w Krzeszowie w świetle badań historycznych, „PERSPECTIVA Legnickie Studia Teologiczno-Historyczne”, R. 8, 2009, nr 1 (14), s. 252.
} 


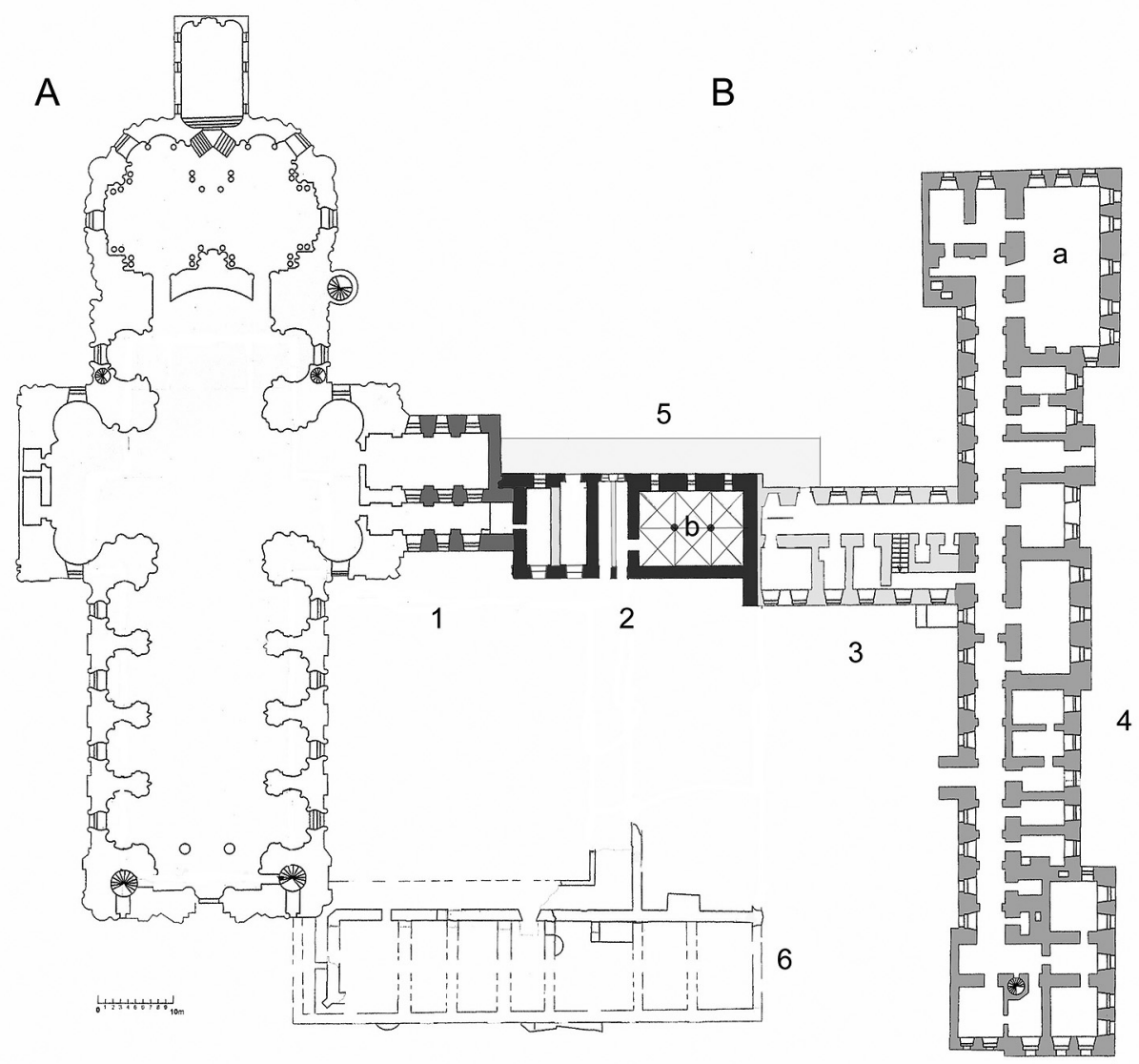

Il. 2. Rzut przyziemia claustrum krzeszowskiego. A-kościół klasztorny, B-budynek klauzury, części : I - ok I730, 2-XIV w.-4 .ćw. XVIII w., 3-I788-92, 4-I738, 5-I932, 6 - relikty odstonięte $w$ czasie badań 2007-2008, a-fraternia (obecnie tzw. Sala Rycerska), b-biblioteka, oprac. E. Eużyniecka

\section{Przekształcenia konserwatorskie}

Prace konserwatorskie prowadzone w okresie powojennym na terenie opactwa krzeszowskiego w różnym stopniu dotyczyły poszczególnych części budynku klauzury. Budynek ten nie jest budowlą jednorodną, lecz złożoną z pięciu odróżniających się stylistycznie części (il.2). Część pierwsza została zbudowana w stylu barokowym ok. I730 przez Antoniego J. Jentscha, jest połączona z południowym ramieniem transeptu kościoła i mieści fragment krużganku. Środkowa, niższa część została przebudowana po pożarze przez M. Schupperta po roku 1677 z wykorzystaniem starych elementów z zachowaną w przyziemiu fraternią, zwaną obecnie Salą Rycerską. Trzecia część, zbudowana została przez J. J. Rudolfa z Opola w stylu przejściowym między późnym barokiem a klasycyzmem. Czwarta część, największa, to powstałe w latach I738-I792 skrzydło południowe o dwóch ryzalitach, silnie wysuniętych po bokach (il.3). Środek tej części zaakcentowany jest niewydatnym ryzalitem z frontonem. 


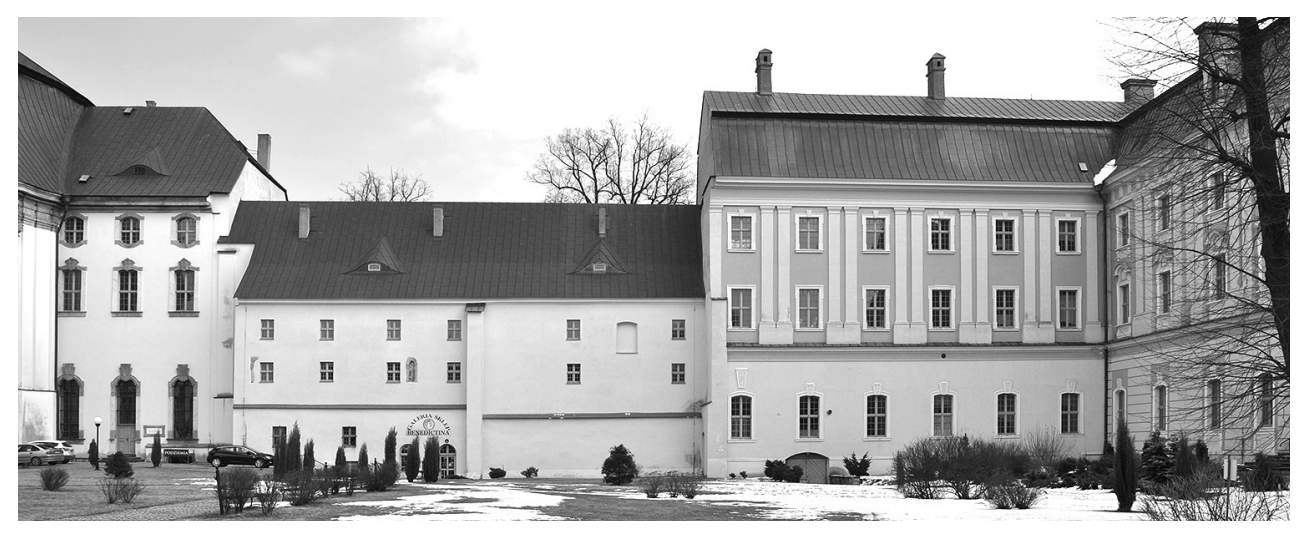

\section{Il. 3. Widok budynku klauzury od strony zachodniej,20I8, fot. Adam Biela}

Elewacje skrzydła południowego zaprojektowane zostały w wielkim porządku na cokole ozdobionym boniowaniem. Jego wnętrza mieszczą refektarz letni i zimowy, kuchnię konwentu i cele, których wystrój jest bardzo oszczędny. Najokazalszym pomieszczeniem jest umieszczona we wschodniej części budynku biblioteka z antresolą, zajmująca wysokość dwóch kondygnacji i wyposażona w meble o formach klasycystycznych. Piątą i najmniejszą część budynku klauzury stanowi dwukondygnacyjny korytarz przystawiony do wschodniej ściany skrzydła wschodniego w 1932 r. Na dolnej kondygnacji arkadowej korytarza opiera się mur o konstrukcji szkieletowej z drewnianych okrąglaków i ceglanego wypełnienia.

Powojenne przekształcenia konserwatorskie budynku klauzury w Krzeszowie związane są z losami ich użytkowników. Do 1954 r. w klasztorze przeprowadzano niewielkie bieżące naprawy dachów ${ }^{\mathrm{II}}$.

W latach 6o. w najstarszej części klasztoru stwierdzono spękanie sklepień i nadproży spowodowane zawilgoceniami. W I969 r. $^{\text {I2 }}$ przeprowadzono prace zabezpieczające, obejmujące wymianę pokrycia dolnej połaci dachu mansardowego od północy. Podobnie jak w przypadku dachu na kościele, wymieniono pokrycie z dachówki ceramicznej na blachę miedzianą na nowym deskowaniu. Brakowało okien i oszkleń skrzydeł okiennych, wyniszczony był system odprowadzania wód opadowych. Planowano wymianę elementów konstrukcyjnych więźby: murłat, słupów, wymian, zastrzałów, a także części legarów oraz podłóg strychowych, które zamieniono na deski o gr. $38 \mathrm{~mm}$. Wymieniono także rury spustowe i opierzenia blacharskie, wstawiono nowe rynny z blachy cynkowej. Wykonano poważniejsze prace dekarskie. W dokumentacji zwrócono uwagę, że ściany ryzalitu wschodniego, gdzie znajdowała się biblioteka, są zarysowane na całej wysokości. Elewacja południowa miała duże spękania

\footnotetext{
11 Zespół zabytkowy w Krzeszowie. Studium organizacji i realizacji prac konserwatorskich, opr. A. Wolski, Przedsiębiorstwo Państwowe Pracownie Konserwacji Zabytków Wrocław - dalej PP PKZ 1978 (mps, Archiwum Wojewódzkiego Urzędu Ochrony Zabytków w Jeleniej Górze - dalej WUOZ), nr A-661, notatka z 2004 r. niechronologicznie włączona do zespołu akt.

12 Kosztorys. Klasztor, opr. M. Majka, PP PKZ 1969, WUOZ, sygn. A-663; Prace konserwatorskie na terenie województwa wrocławskiego w latach 1969-1973, opr. R. Motyl, B. Uszałowicz-Piąty, J. Skibińska, Biuro Studiów i Dokumentacji Zabytków - dalej BSiDZ, Narodowy Zakład Imienia Ossolińskich, Wrocław-Warszawa-Kraków-Gdańsk 1976, s. 48; W. Kapałczyński, Prace remontowo-konserwatorskie w okresie powojennym. Stan obecny zabytków zespołu w Krzeszowie, w: Krzeszów uświęcony..., op. cit., s. 361, 369.
} 
w pionach okien, gdzie zarysowane były niemal wszystkie nadproża. Zwrócono uwagę na spękania sklepień w pomieszczeniach nad biblioteką i w korytarzach. Pokrycie dachu było zniszczone i powodowało zacieki i uszkodzenia tynku.

W 1977 r. część klasztoru przylegająca bezpośrednio do kościoła, w której znajdowała się zakrystia, była pokryta dachówką ceramiczną, karpiówką układaną w rybią łuskęę ${ }^{13}$. Fundamenty i mury pracowały pod względem statycznym prawidłowo. Na ścianach uszkodzony był tynk, sklepienie nad korytarzem I pietra zarysowane było w zworniku na całej długości. Schody zewnętrzne stoczone były przez drewnojady, podłogi drewniane na wyższych kondygnacjach były uszkodzone. Kraty w oknach korodowały, a stolarka drewniana była uszkodzona. Gotycki budynek łączący kościół z klasztorem barokowym miał w tym czasie uszkodzone elewacje, przy zarysowanych w kilku miejscach pionowo ścianach wyrosła trawa, zarysowane były sklepienia nad korytarzami, zarówno w układzie poprzecznym jak i wzdłużnym, tynk na elewacjach łuszczył się i odpadał na dużych płaszczyznach. Zabytkowe ceramiczne podłogi zachowane w przyziemiu były miejscami w znacznym stopniu wytarte, połupane i odkształcone. W tym czasie dokonano także oceny stanu zachowania przybudówki elewacji wschodniej z I932 r. Drewniany szkielet budowli był w znacznym stopniu uszkodzony.

Klasztor w tym czasie był ogólnie w dobrym stanie zachowania, aczkolwiek ściany wschodniego ryzalitu były zarysowane na całej wysokości, filary na poziomie piwnic i wyższych kondygnacji nie pracowały równo i nie osiadały jednakowo, pracując jako oddzielne elementy, co powodowało pękanie sklepień. Spękania widoczne były także na elewacjach skrzydła południowego, szczególnie na osiach okien. Zarysowane były sklepienia korytarzy klasztornych i pozostałych pomieszczeń, zwłaszcza w zwornikach. Zwracano uwagę, że zarysowania nie stanowiły w tamtym momencie bezpośredniego zagrożenia, ale konieczna była ich obserwacja. Ściany w piwnicach i na parterze były zawilgocone i porośnięte na zewnątrz trawą. Stropy III piętra były odkształcone, uszkodzenia tynku naprawiano okresowo. Stopnie schodów były wytarte, przemieszczone i uszkodzone. Konstrukcja więźby była w tamtym czasie w dobrym stanie, impregnowana materiałem oleistym. Na ścianach widoczne były zacieki i uszkodzenia tynków, spowodowane nieszczelnością, brakiem rynien i uszkodzeniem koszy. Wewnątrz wszystkie posadzki były w dość dobrym stanie zachowania, z niewielkimi odkształceniami, śladami napraw i uzupełnień, częściowo pokryte nawierzchnią z tworzyw syntetycznych. Okna były częściowo wymienione w okresie powojennym ${ }^{14}$. W I978 r. wymieniona została stolarka okienna na korytarzu budynku klasztornego ${ }^{15}$.

W latach 70. w klasztorze przeprowadzono malowanie wnętrz. Stan zachowania wnętrza był wówczas dość dobry, piwnice wolne były od agresji biologicznej. W gorszym stanie była część bezpośrednio sąsiadująca z kościołem, gdzie w piwnicy występowało zawilgocenie i częściowe zawodnienie, w pomieszczeniu ze studzienką występowała grzybnia i owocniki stroczka łzawego, na parterze zawilgocenie i korozje tynków, w szkieletowej przybudówce zagrzybienie powłocznikiem gładkim, w przybudówce do skrzydła południowego część

\footnotetext{
13 Konstrukcja. Wstępna opinia o stanie technicznym obiektów położonych w Krzeszowie, opr. St. Wojdon, PP PKZ 1977 (mps, WUOZ), sygn. nr A/A-654, s. 12-21.

14 Tamże.

15 Prace konserwatorskie na terenie województw jeleniogórskiego, legnickiego, wałbrzyskiego, wrocławskiego w latach 1974-1978, opr. K. Bartnik et. al., kons. meryt. E. Lenkow, BSiDZ, wyd. Zakład Narodowy im. Ossolińskich, Wrocław-Warszawa-Kraków-Gdańsk-Łódź 1985, s. 31.
} 
elementów stropodachu była zaczerwiona i porażona kołatkami. Na skorodowanych tynkach wewnątrz pomieszczeń parteru występowały pleśnie. Podobnie także na wysokości piętra podłogi drewniane porażone były przez kołatka, korozje tynków występowały tu w znacznie mniejszym stopniu, aniżeli w parterze. Podłogi drugiego piętra porażone były kołatkiem, więźba - tylko w najstarszych częściach. W miejscach zacieków spowodowanych nieszczelnościami pokrycia dachu, występowało gniazdowe zagrzybienie wroślakiem rzędowym w stanie zahamowanym ${ }^{16}$.

W latach 1982-1984 wymieniono pokrycie dachu ryzalitu wschodniego, zamiast dachówki położona została blacha miedziana. Zachodnią elewację średniowiecznego skrzydła klasztoru wyremontowano w $1998 \mathrm{r}^{17}$.

Nowy okres w konserwacji budynku klasztornego w opactwie krzeszowskim rozpoczął się na początku obecnego stulecia, gdy dostrzeżono korzyści związane z przystąpieniem Polski do Unii Europejskiej i pojawiły się nowe możliwości finansowania projektów ukierunkowanych na ratowanie najcenniejszych zabytków dziedzictwa kulturowego. Diecezja Legnicka przygotowała długofalowy program przywracania dawnej świetności zabytków nieruchomych i ruchomych pt: „Rewaloryzacja Zespołu Opactwa Cystersów wraz z otoczeniem w Krzeszowie". Pierwsze prace koncepcyjne rozpoczęto już w $1999 \mathrm{r}^{18} \mathrm{Na}$ początku skoncentrowano się na domu opata - rewaloryzacja tego obiektu z adaptacją na dom gościnny została uhonorowana I nagrodą w konkursie „Modernizacja Roku 2002” w kategorii „Budynki Zabytkowe”. Ten fakt zapewne pomógł w uznaniu zespołu za Pomnik Historii, co nastąpiło w $2004 \mathrm{r}$.

Wstępnym etapem programu rewaloryzacji domu klauzury było opracowanie projektu budowlanego i w 2005 r. projektu wykonawczego remontu klasztoru ${ }^{19}$. W dokumentacjach zwracano uwagę na historyczne i artystyczne wartości obiektu, zachowanie historycznych układów pomieszczeń, zabytkowych wnętrz, korytarzy, klatek schodowych oraz elewacji. Planowano osuszenie ścian i włączenie budowli do systemu drenażowego, remont i zabezpieczenie biologiczne więźby, ocieplenie korony murów, naprawę i wymianę opierzeń blacharskich, przemurowanie i wzmocnienie rys na ścianach i sklepieniach, konserwację barokowych podłóg z drewna i posadzek kamiennych i klinkierowych oraz wykonanie nowych posadzek w miejscu wtórnych cementowych. W ramach modernizacji zaproponowano przebudowę kuchni, wprowadzenie windy, wydzielenie pokoi z łazienkami, wykonanie nowych pomieszczeń sanitarnych, ścianek działowych z cegły ceramicznej i płyt kartonowo-gipsowych, przebicie nowego otworu drzwiowego z Sali Rycerskiej w gotyckiej części na dziedziniec klasztoru, a także zamurowanie niektórych istniejących otworów drzwiowych $\mathrm{z}$ zachowaniem fragmentów stolarki oraz wymianę drzwi na strych.

\footnotetext{
16 Kompleksowa opinia mykologiczno-budowlana. Rozpoznanie wstępne agresji biotycznej, opr. B. Kuzynków, PP PKZ 1977, WUOZ, sygn. nr A/A-653, s. 8-17.

17 Prace konserwatorskie na terenie województwa dolnośląskiego w latach 1979-1999, red. G. Grajewski, E. Kica, Wojewódzki Urząd Ochrony Zabytków we Wrocławiu, Wrocław 2005, s. 174.

18 Pisze o tym arch. A. Baran w swoich wspomnieniach z prac projektowo-konserwatorskich pt. Krzeszów, klasztor - pogmatwane dzieje, http://szpakowedrzewo.blogspot.com/2014/01/pogmatwane-dzieje.html (dostęp: 10.07.2018 r.

19 Projekt techniczny remontu klasztoru w Zespole pocysterskim w Krzeszowie. Architektura i konstrukcja. Budynek klasztorny, proj. A. Baran, Świdnica 2005, WUOZ, sygn. nr A-29/94.
} 
Części projektowej towarzyszyło wiele badań, m.in. przeprowadzono badania stratygraficzne nawarstwień tynków i polichromii. W ich wyniku kolorystyka elewacji została całkowicie zmieniona. Klasycystyczne szarości zostały zastąpione barokowym złotym ugrem i dwoma odcieniami zieleni. Innym rodzajem badań były analizy architektoniczne, które zostaną opisane w kolejnym paragrafie.

Wspomniany projekt rewaloryzacji klauzury realizowano w kilku etapach. W latach 2006-2008 otrzymano dofinansowanie z funduszy europejskich w ramach Zintegrowanego Programu Operacyjnego Rozwoju Regionalnego. Pozyskane w ten sposób kwoty i środki własne diecezji oraz wsparcie finansowe innych instytucji, np. Ministerstwa Kultury i Dziedzictwa Narodowego, KGHM Polska Miedź SA, pozwoliły na zrealizowanie prac, które zaowocowały renowacją stolarki okiennej i elewacji budynku klasztornego. Bardzo istotnym elementem prac była konserwacja elewacji, polegająca na wzmocnieniu zachowanych barokowych tynków, konserwacji detali sztukatorskich, konserwacji elementów kamiennych oraz malowaniu elewacji zgodnie z pierwotną koncepcją. Obejmowała ona także konserwację schodów, wymianę istniejącej stolarki z zachowaniem kształtu i dotychczasowych form oraz konserwację zachowanych drzwi. W 2008 r. trwały prace konserwatorskie skrzydła klasztornego. W czasie prac planowano powiększenie trzech otworów okiennych w zachodnim ryzalicie i przystosowanie obiektu dla osób niepełnosprawnych ${ }^{20}$. Ponadto adaptowano i wyposażono część pomieszczeń klasztornych na centrum konferencyjne oraz pokoje gościnne. Zrewaloryzowano również otoczenie opactwa ${ }^{21}$.

Drugim etapem realizacji tego projektu było przedsięwzięcie pt.: Odbudowa, zachowanie i efektywne wykorzystanie dziedzictwa kulturalnego o znaczeniu ponadregionalnym - Zespołu Opactwa Cysterskiego w Krzeszowie. W 2009 r. pomiędzy Diecezją Legnicką a Ministrem Kultury i Dziedzictwa Narodowego została podpisana umowa o dofinansowanie projektu ze środków Europejskiego Funduszu Rozwoju Regionalnego w ramach Programu Operacyjnego Ochrona i Środowisko, Priorytet II „Kultura i dziedzictwo kulturowe”, Działanie II.I ,Ochrona i zachowanie dziedzictwa kulturowego o znaczeniu ponadregionalnym”. Następnie rozpoczęły się roboty budowlane i prace konserwatorskie związane z adaptacją obiektów na cele kulturalne i zakup trwałego wyposażenia do prowadzenia działalności kulturalnej w tych obiektach oraz zabezpieczenie zabytków przed kradzieżą i zniszczeniem, a także konserwacja zabytków ruchomych ${ }^{22}$. Prace te zaowocowały m.in. realizacjami, które otrzymały prestiżową nagrodę Dolnośląski Laur Konserwatorski w 20II r.

Prace konserwatorskie obejmujące budynek klauzury opactwa krzeszowskiego były wspomagane w czasie realizacji największym w Polsce projektem związanym ze szlakami kulturowymi pod nazwą „Południowo-zachodni Szlak Cystersów”23, realizowanym w latach 2008-20II. Korzystając z dofinansowania z Europejskiego Funduszu Rozwoju Regionalnego, zaplanowano wybudowanie i zmodernizowanie całej infrastruktury turystycznej przy obiek-

\footnotetext{
20 Projekt budowlany zmiany remontu klasztoru $w$ zespole pocysterskim $w$ Krzeszowie. Architektura i konstrukcja, opr. A. Baran, Świdnica 2008, WUOZ, sygn. nr A-14/382.

${ }_{21}$ Rewaloryzacja - etap II, http://www.opactwo.eu/index.php/co-nas-czeka-2/18-sanktuarium-matki-boej-askawej/ue/128-rewaloryzacja-etap-ii (dostęp: 10.07.2018).

22 Tamże.

23 M. Sierpowska-Kaczmarek, Południowo-zachodni Szlak Cysterski. Założenia i realizacja nowego produktu turystycznego, w: Przyszłość badań nad historia i kulturą cysterską w Polsce, red. E. Łużyniecka, A. Galar, Wrocław 2011, s.243-256.
} 

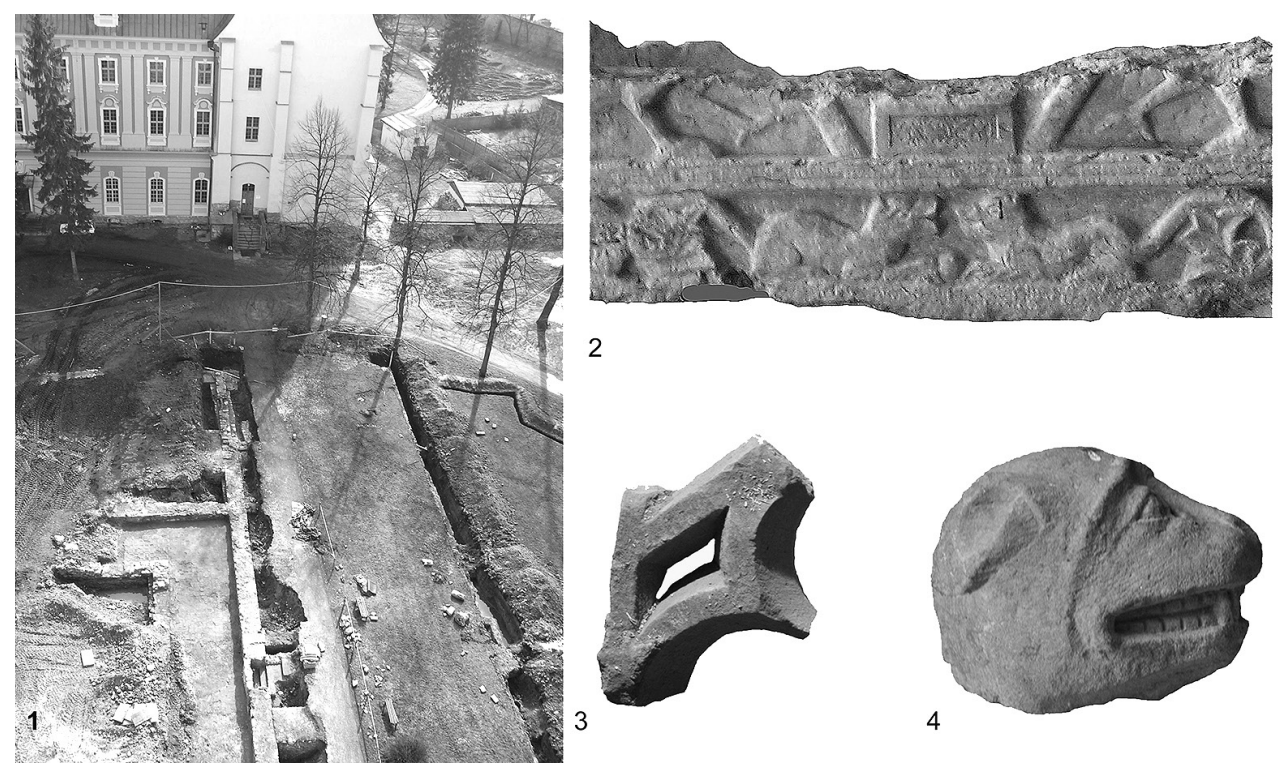

2
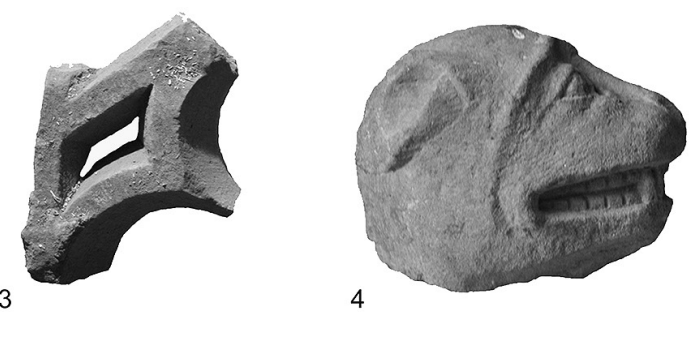

Il. 4. Relikty średniowiecznego budynku klauzury. I - mury odsłonięte w 2007-2008 r., widok z wieży kościoła, 2 - element rzeźbiarski, 3 -fragment maswerku, 4-główka lwa, fot. E. Łużyniecka

tach pocysterskich. Powstały parkingi, punkty informacji turystycznej, jednorodny system oznakowania obiektów, oznakowania drogowego oraz spójny dla całego szlaku system informacji turystycznej, udostępnianej w sieci. Z otrzymanej kwoty poważna część środków została również przeznaczona na kampanię promocyjną w kraju i za granicą.

\section{Badania architektoniczne}

Częścią opisanego wcześniej wielkiego programu rewaloryzacji dawnego zespołu opactwa cystersów wraz z otoczeniem w Krzeszowie było zagospodarowanie placu kościelnego i remont najstarszej części klauzury, który stał się pretekstem do podjęcia badań architektonicznych w latach 2007-2008 (il. 4, I), a następnie od 20I4 r. Podstawowym problemem badawczym było rozpoznanie reliktów średniowiecznej klauzury.

Ważnych informacji o rozplanowaniu i architekturze nieistniejącego dziś klasztoru dostarcza analiza miedziorytu Hansa Tscherninga wg rysunku Willmanna z I678 r. ${ }^{24}$, na którym wiele budowli ma jeszcze średniowieczną formę. Do nich należy trzyskrzydłowy, dwupiętrowy budynek klauzury z jednokondygnacyjnym krużgankiem obiegającym wirydarz i skrzydłem zachodnim, znacznie wysuniętym przed elewację zachodnią kościoła. Wspomniane skrzydło zachodnie oraz wschodnie zostały częściowo rozebrane w czasie budowy nowego kościoła, co uwiecznił nieznany autor w połowie XVIII w. (płótno przechowywane w Muzeum Ziemi Kłodzkiej).

${ }^{24}$ H. Dziurla, Krzeszów..., op. cit., s. 23. 
Wymienione przekazy ikonograficzne były do tej pory głównymi wskazówkami w odtwarzaniu średniowiecznego klasztoru. Spośród wielu opracowań architektonicznych na uwagę zasługują wspomniane już prace Henryka Dziurli, który uważał, że pierwszy klasztor był raczej drewniany, a istniejące w skrzydle wschodnim pomieszczenie, pełniące funkcję fraterni datował na połowę XV w. Rozważania wspomnianego autora były punktem wyjściowym prac Mariana Kutznera ${ }^{25}$, który inaczej od poprzednika określał czas powstania pomieszczenia klasztornego. Twierdził, że fraternia powstała w I. ćwierci XVI w.

Prof. Ewa Łużyniecka zajęła się opactwem krzeszowskim po raz pierwszy ponad dwadzieścia lat temu ${ }^{26}$, ale dopiero wspomniane prace ziemne w latach 2007-2008 pozwoliły na poszerzenie wiedzy na temat średniowiecznego budynku klauzury ${ }^{27}$. Wówczas został powołany pierwszy zespół kierowany przez autorkę (dalej ZWAPWr). W skład zespołu wchodzili następujący absolwenci oraz studenci Wydziału Architektury Politechniki Wrocławskiej: Izabela Przybylska, Paulina Michnik, Paulina Bakuła, Aleksandra Dobrowolska, Izabela Grzelak, Krzysztof Wyrwa, Małgorzata Zielińska, Paweł Ziembicki, Zofia Zięba. W ramach prac wykonano inwentaryzacje rzutów i elewacji reliktów średniowiecznych, analizy strukturalne murów i stratygrafię budulca elewacji ${ }^{2}$. Drugi zespół powstał w 20I4 r., przy okazji realizacji wspomnianego na początku projektu badawczego i kierowały nim obie autorki artykułu. W pracach uczestniczyli doktoranci i studenci: Luba Smirnowa, Adam Bela, Monika Smorąg, Gabriela Szmyd.

W trakcie prowadzenia badań architektonicznych w 2007 r. przeprowadzono próbę datowania zapraw metodą rozkładu węgla I4C. Pobrano 4 próbki zapraw, wydobywając je z przestrzeni między kamieniami zaraz po odsłonięciu murów. Następnie próbki przekazano do Laboratorium Radiowęglowego przy Uniwersytecie im. Adama Mickiewicza w Poznaniu. Tam, pod kierunkiem prof. Tadeusza Goslara, przy użyciu mikroskopu wybierano z próbek drobiny węgla, które dostawały się do wapna w trakcie procesu wypalania ${ }^{29}$. Następnie datowano je metodą analizy radioaktywnej węgla I4C. Spośród pobranych próbek zapraw tylko jedna zawierała drobiny węgla i tylko one zostały poddane badaniom laboratoryjnym, które pozwoliły określić daty powstania zaprawy. Z prawdopodobieństwem od $68,2 \%$ do $54 \%$, zaprawę datowano na lata I520-I600 lub na lata I620-I650. Z prawdopodobieństwem $95,4 \%$ zaprawę datowano na lata I450-I650.

Przeprowadzone badania architektoniczne pozwoliły na przedstawienie kilku wniosków dotyczących przeobrażeń budynku klauzury opactwa krzeszowskiego. W średniowieczu

\footnotetext{
25 M. Kutzner, Cysterska architektura na Śląsku w latach 1200-1330, Toruń 1969, s. 45; idem, Średniowieczna architektura klasztoru cysterskiego w Krzeszowie, w: Krzeszów uświęcony..., op. cit., s. 132-140.

26 E. Łużyniecka, Architektura średniowiecznych klasztorów cysterskich filiacji lubiąskiej, Wrocław 1995, s. 143149; eadem, Architektura klasztorów cysterskich. Filie lubiąskie i inne cenobia śląskie (The architecture of Cistercian monasteries. Daughter houses of Lubiaż and other Silesian cenobia), Wrocław 2002, s. 529-531.

27 Badania skrzydła zachodniego klauzury towarzyszyły nadzorowi archeologicznemu Wojciecha Grabowskiego i stanowiły punkt wyjściowy do opracowania koncepcyjnych projektów konserwatorskich.

28 Opis badań zob. E. Łużyniecka, Średniowieczny klasztor cysterski w Krzeszowie na podstawie ostatnich badań architektonicznych, „Architektura. Czasopismo Techniczne”, 7-A/2011, z. 23, R. 108, s. 441-460.

29 W Polsce propagatorem tej metody stał się prof. Andrzej Wyrwa z Uniwersytetu Poznańskiego. A. M. Wyrwa, O możliwościach datowania zapraw metoda 14C w obiektach architektonicznych, „Wielkopolski Biuletyn Konserwatorski”, I/2002, s. 169-181. Autorka stosowała tę metodę w badaniach klasztorów w Pelplinie i Doberanie - zob. E. Łużyniecka, Pelplin i Doberan. Architektura opactw cysterskich spokrewnionych filiacyjnie, Wrocław 2014, s. 794-802.
} 
wschodnie skrzydło klauzury było zapewne jednopiętrowe, wyższa kondygnacja została zbudowana później. Ściana zachodnia skrzydła o wysokości około $9,80 \mathrm{~m}$ była tynkowana i zbudowana z kamieni otoczaków oraz ciosów. Na wysokości 5,80 m zachowała się odsadzka, prawdopodobnie stanowiąca oparcie więźby krużganka oraz pośrednio wyznaczająca wysokość sklepień parteru skrzydła. Poniżej odsadzki ściana parteru została prawie całkowicie oblicowana w czasach nowożytnych, wówczas wykonano także obecne okna i przejścia, dlatego nie zachowały się w niej pierwotne otwory i ślady po średniowiecznych sklepieniach.

Na parterze skrzydła wschodniego przetrwało do dziś kilka pomieszczeń. Niezidentyfikowane do tej pory wąskie pomieszczenie północne jest prawdopodobnie reliktem mocno zniszczonego kapitularza. Ściana południowa pomieszczenia jest zapewne południową ścianą kapitularza. W ścianie północnej pomieszczenia natomiast zachował się widoczny od zewnątrz ostrołuk, sięgający do wysokości wcześniej opisanej odsadzki. Jest to prawdopodobnie pozostałość konstrukcji sklepienia, być może gurtu albo żebra międzyprzęsłowego. Wskazuje na to znaczna wysokość ostrołuku i jego położenie.

Na południe od domniemanego kapitularza znajdowała się prawdopodobnie jednobiegowa klatka schodowa, obecnie pozbawiona schodów i wtórnie sklepiona. Obecna natomiast dwubiegowa klatka schodowa powstała w czasach nowożytnych. Wówczas do wnętrza średniowiecznej sieni wstawiono konstrukcję schodów, wykonano także nowe sklepienie i półkoliście zwieńczone wejścia.

W ścianie południowej sieni skrzydła wschodniego zachował się relikt pierwotnego przejścia do fraterni, sąsiadującej z pomieszczeniem skrzydła południowego. Fraternia, obecnie tzw. Sala Rycerska, do dziś jest sześcioprzęsłową salą, którą przykrywa sklepienie krzyżowo-żebrowe wsparte na dwóch słupach. Pierwotnie posadzka fraterni znajdowała się około I,IO m poniżej obecnej, a okna zostały przemurowane w czasach nowożytnych. Nad pomieszczeniami parteru znajdowało się zapewne dormitorium. W czasie badań zlokalizowano jego ścianę zachodnią o wysokości około $3,80 \mathrm{~m}$ z wąskimi ostrołucznymi oknami. Kamienne obramienia okien tak wyżłobiono, by można było w nich umieścić prostokątne okiennice.

W trakcie badań stwierdzono także, że pierwotne, nieistniejące dziś skrzydło zachodnie klauzury było zaprojektowane symetrycznie. Na osi skrzydła znajdowało się wejście główne, pod pomieszczeniami parteru skrzydła umieszczono piwnice, których okna były widoczne w elewacji zachodniej. W czasie badań architektonicznych w 2008 r. odsłonięto pięć piwnic, łęki otworów okiennych i relikt przejścia głównego. Z okresem średniowiecza można jednak wiązać tylko niektóre fragmenty murów. W tym czasie powstał prawdopodobnie wzmocniony przyporą północno-zachodni narożnik domu zachodniego. Narożnik zbudowano z kamieni łączonych gliną przemieszaną z piaskiem oraz niewielką ilością wapna. Relikt ten obecnie jest oddalony od kościoła. Dlatego prawdopodobnie także w średniowieczu dom zachodni nie stykał się ze świątynią cysterską.

Na podstawie przeprowadzonych badań można także określić sposób przekształcenia domu zachodniego w zachodnie skrzydło klauzury. Prawdopodobnie działania te miały miejsce jeszcze $w$ średniowieczu i były połączone $\mathrm{z}$ równoczesną budową skrzydła południowego. Mury w tej części utworzono nie tylko z kamieni, jak to miało miejsce wcześniej, ale także z fragmentów cegieł i połączono je zaprawą wapienną. Z tego okresu w czasie badań były dostępne jedynie ściany oddzielające pomieszczenia skrzydeł od krużganka. Nie udało 
się ustalić lokalizacji ścian zewnętrznych, choć należy przypuszczać, że ściana zachodnia ówczesnego skrzydła zachodniego znalazła się na przedłużeniu ściany z przyporą.

Opisane skrzydło zachodnie w czasach nowożytnych zostało całkowicie przebudowane. Rozebrano elewację zachodnią oraz północną skrzydła i zbudowano nowe ściany w odległości około 4,0 m od starych. Nie zmieniono jedynie ściany wschodniej, zapewne ze względu na konstrukcję krużganka. W ten sposób powierzchnia budowli znacznie się zwiększyła - powstało skrzydło o szerokości I4,20 m i długości około $59 \mathrm{~m}$. Zachowana ściana zachodnia została wzniesiona w czasach nowożytnych z łączonych zaprawą wapienną cegieł o układzie główkowym oraz kamieni łamanych.

Podziały wewnętrzne skrzydła zachodniego wykonano, dostawiając ściany działowe do muru wschodniego - dostawienia te podczas badań były wyraźnie widoczne. Tym samym w części północnej i środkowej skrzydła utworzono piwnice, dostępne od strony krużganka. Piwnice zostały przykryte sklepieniami kolebkowymi, opartymi na ścianach wschodnich i zachodnich. Kolebki zbudowano być może w pewnym odstępie czasu. Różnią się bowiem budulcem. Jedna kolebka została zbudowana z kamieni, inne z cegieł.

Z czasów nowożytnych pochodzą także prawdopodobnie analizowane fragmenty ścian krużganka, co nie wyklucza istnienia pod nimi reliktów wcześniejszych. Zarówno relikt odkryty w $2000 \mathrm{r}^{30}$, jak i mury zarejestrowane ostatnio, zbudowano z niestarannie ułożonych cegieł nowożytnych i kamieni. Fragmenty murów w narożniku południowo-zachodnim można interpretować jako pozostałości dwóch wnęk okiennych. Podobne okna znajdują się w nowożytnym krużganku opactwa henrykowskiego i umieszczone są w łękach sięgających do podłogi. Ściany pod parapetami są wąskie, zbudowane na szerokość jednej cegły. W podobny sposób zostały wykonane także okna fraterni w Krzeszowie.

Metrykę nowożytną mają także posadzki ceramiczne, które zachowały się w krużganku i w sieni środkowej skrzydła zachodniego. Relikt posadzki zachował się także w przejściu między skrzydłem zachodnim i południowym. W tym miejscu przetrwał także relikt pieca, związanego zapewne z kuchnią klasztorną.

W czasie badań architektonicznych, oprócz odsłonięcia reliktów murowanych, z warstw gruzu wydobyto fragmenty kamiennych maswerków, które przechowywane są obecnie w magazynie klasztoru. Oprócz tego znajdują się tam także detale znalezione podczas innych prac badawczych i remontowych: dachówki, płytki posadzkowe, fragment wylotu z pieca ogrzewczego, profilowane fragmenty pilastrów i opasek okiennych, część tablicy z datą I589, kamienna główka lwa. Należy także wspomnieć o bogato dekorowanym renesansowym elemencie rzeźbiarskim, który jest eksponowany w domu opackim (il. 4, 2-4).

Na podstawie przeprowadzonych analiz można także dokonać próby datowania ostatnio odsłoniętych reliktów. Trudno jest jednoznacznie określić czas powstania pierwszego domu zachodniego - nie zachowały się z tego czasu detale architektoniczne, a sposób budowy muru nie pozwala na datowanie. Jedynym elementem jest przypora przekątniowa, której powstanie można wiązać nawet z połową XIII w. W tym czasie zbudowano prawdopodobnie np. przypory kościoła dominikanów św. Wojciecha we Wrocławiü ${ }^{31}$.

\footnotetext{
30 Właśnie wówczas odsłonięto fragment ściany zachodniej wschodniego krużganka - zob. T. Wrocławski, Sprawozdanie z nadzoru archeologicznego prowadzonego w wirydarzu klasztoru w Krzeszowie, 2000 (mps, WUOZ).

31 E. Małachowicz, Wczesnośredniowieczna architektura kościoła dominikanów we Wrocławiu, „Kwartalnik Architektury i Urbanistyki", 1975, t. 20, z. 1, s. 22.
} 
Nowo odkryte elementy fraterni pozwalają na porównanie form gotyckiego opactwa krzeszowskiego do architektury jego siostrzanej filii w Kamieńcu Ząbkowickim. Budowa korpusu kamienieckiej hali zgodnie datowana jest na lata 1300 - połowa XIV w.3. ${ }^{32}$, dlatego powstanie fraterni krzeszowskiej można datować na czas między powstaniem kościoła kamienieckiego w połowie XIV w. a konsekracją świątyni krzeszowskiej w I454 r. Analogiczne detale można znaleźć w czeskiej architekturze cysterskiej - podobne do krzeszowskich słupów służki sklepień krużganka w Zlatej Korunie są datowane na ostatnią ćwierć XIV w.33. Można więc przypuszczać, że pod koniec XIV w. funkcjonowało już skrzydło wschodnie klauzury i wolnostojący dom konwersów opactwa krzeszowskiego. Prace budowlane trwały jednak zapewne dalej w kolejnych stuleciach. W XV w. być może zbudowano trzecie skrzydło budynku klauzury. W przedstawionym wcześniej dokumencie konsekracyjnym kościoła klasztornego w I454 r. - obok cmentarza, ambitu (krużganka?), kapitularza i dormitorium - wymieniono bowiem także refektarz, który zwykle znajdował się w skrzydle południowym. $\mathrm{Z}$ tego czasu mogą więc pochodzić mury odsłonięte w południowo-zachodnim narożu klauzury.

Kroniki klasztorne informują także o trwających pracach budowlanych jeszcze w I52I i 1562 r. - z tego czasu pochodzi wzmianka o mistrzu budowlanym Krzysztofie Włochu. Pracowali wówczas zapewne dobrzy kamieniarze, ponieważ zachowane detale renesansowe charakteryzują się wysokim poziomem warsztatowym. $Z$ tym czasem należy także wiązać półkoliście zwieńczony otwór w zachodniej ścianie dormitorium mnichów.

W tym kontekście, znana z przekazów pisanych i ikonografii przebudowa klasztoru krzeszowskiego, wykonana z inicjatywy opata Bernarda Rosy w latach I662-I668, była tylko kolejną modernizacją budynku klauzury. To przedsięwzięcie, kierowane przez sprowadzonego z Czech muratora M. Schupperta, jest najwcześniejszym na Śląsku przykładem wprowadzania do tradycyjnego schematu klasztornego cech rezydencjonalnej reprezentacyjności, charakterystycznej dla baroku ${ }^{34}$.

Jest to o tyle ważne, że doświadczenia Schuperta zostały być może wykorzystane dwadzieścia lat później przez budowniczego Mateusza Kirchbergera, mieszkańca Henrykowa, który w latach I682-I688 zaprojektował i kierował przebudową opactwa henrykowskiego. W obu budowlach można zaobserwować podobny sposób rozplanowania skrzydeł zachodnich. Są one podpiwniczone i poziomy użytkowe parteru są wyżej od posadzek krużganka. W obu też budowlach na osi znajdowało się wejście główne, a ściana między krużgankiem a skrzydłem miała średniowieczną metrykę.

Kolejna XVIII-wieczna przebudowa klauzury krzeszowskiej jest zdarzeniem wyjątkowym w śląskim budownictwie cysterskim. Tylko w tym przypadku zdecydowano się na drugą przebudowę barokową. Dzięki zapewne nadal funkcjonującym wielkim latyfundiom, cystersi krzeszowscy podjęli w latach I774-1789 budowę nowego budynku klauzury o kolosalnej jak na ówczesne warunki śląskie skali. Projekt nie został zrealizowany w całości. Obecnie zachowane części to wybudowane pod kierunkiem J. G. Fellera skrzydło południowe i przedłużenie skrzydła wschodniego wzniesione przez J. J. Rudolfa. Artykulacja

\footnotetext{
32 M. Kutzner, Cysterska..., op.cit., s. 87, M. Untermann, Forma Ordinis. Die mittelalterliche Baukunst der Zisterzienser, Berlin 2001, s. 558.

33 J. Kuthan, Počátky a rozmach gotické architektury v Čechach, Praha 1983, s.252., s. 310.

${ }^{34}$ K. Kalinowski, Architektura doby baroku na Śląsku, op. cit., s. 83.
} 


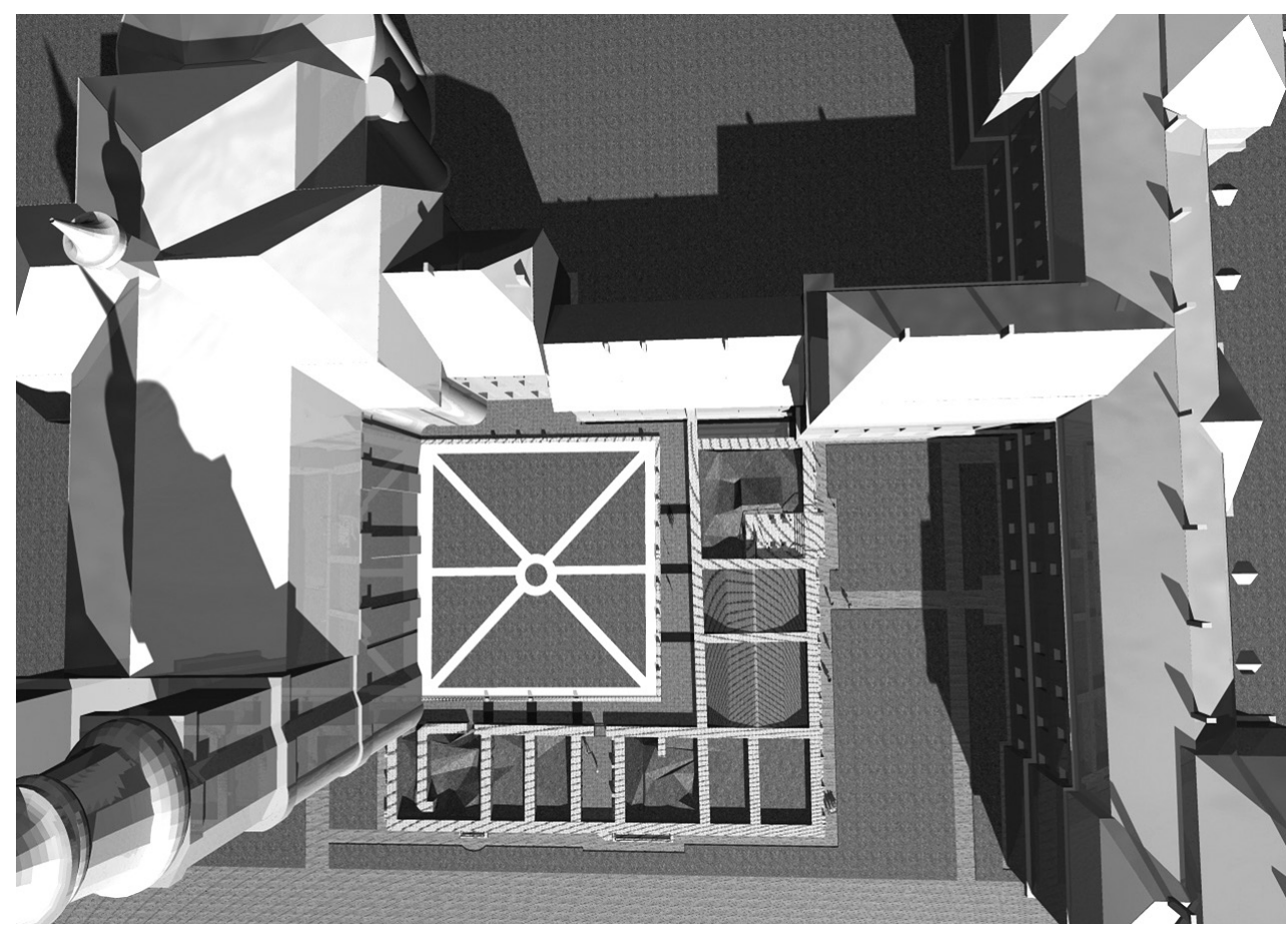

Il. 5. Projekt ekspozycji reliktów średniowiecznego budynku klazury w Krzeszowie, 2008, oprac. $Z W A P W r$

powstałych elewacji przy barokowym charakterze kompozycji całości kształtowana była pod wpływem wczesnego klasycyzmu. Na podstawie obserwacji ścian podczas ostatniego remontu można stwierdzić, że w ścianach tej budowli jest wiele budulca rozbiórkowego (ciosów, fragmentów posadzek i dachówek), a technika wznoszenia ścian przypomina mury z wcześniejszych etapów budowy.

\section{Podsumowanie}

Przedstawiony opis prac konserwatorskich i badawczych budynku klauzury dawnego opactwa cysterskiego w Krzeszowie pozwala wyróżnić dwa okresy w powojennych dziejach konserwacji tego zabytku. Pierwszy to pięćdziesięciolecie powojenne, w którym prace koncentrowały się na remontach bieżących. Sytuację tą dobrze oddają słowa wieloletniego wojewódzkiego konserwatora zabytków Wojciecha Kapałczyńskiego: „Klasztor w całości użytkowany utrzymywany był ogólnie w dobrym stanie - wykonywano remonty dachów, usuwanie zacieków”35.

Sytuacja zmieniła się na początku obecnego stulecia, gdy pojawiły się nowe możliwości finansowania projektów w ramach działań Unii Europejskiej. To sprawiło, że kolejne części krzeszowskiego budynku były remontowane z uwzględnieniem współczesnych potrzeb

35 W. Kapałczynski, Prace remontowo-konserwatorskie w okresie powojennym, op. cit. 
kulturalnych i turystycznych. Proces adaptacji wnętrz nadal trwa i wraz z upływem czasu powstają kolejne pomysły i propozycje następnych działań konserwatorskich i budowlanych.

Jedną z wielkich zalet budynku klauzury opactwa krzeszowskiego jest to, że funkcjonuje tu konwent benedyktynek, co dodaje miejscu autentyzmu. W takich miejscach powstaje szczególna atmosfera, którą dobrze ilustruje opis architekt Anny Baran z 2016 r.: „Siostry utrzymują się z własnego gospodarstwa, mają wielki ogród i pole, gotują, robią przetwory, suszą zioła, a jaki wspaniały chleb wypiekają w starym piecu chlebowym!!! W czasie prac mieliśmy duży kłopot z rozpadającym się kolosem, ale się udało... zapach chleba, raz w tygodniu, unosi się po klasztornych korytarzach... mówię Wam - niebo"’36.

Dodatkową atrakcją dla osób zainteresowanych budynkiem klauzury w Krzeszowie są bardzo ciekawe, opisane w 2017 r., zbiory lwowskie sióstr benedyktynek ${ }^{37}$. Być może w przyszłości można je będzie obejrzeć w muzeum i dodatkowo zwiedzić słynną bibliotekę klasztorną $3^{38}$.

Atrakcyjność tego miejsca bez wątpienia zwiększyłoby utworzenie ekspozycji reliktów średniowiecznego claustrum (il.5). Pod obecną powierzchnią placu kościelnego znajdują się bowiem piwnice i relikty przyziemia skrzydła południowego i zachodniego. Mogą one być w przyszłości udostępnione zwiedzającym. Taka inwestycja byłaby nie tylko atrakcyjna pod względem kulturowym, ale także mogłaby być asumptem do dalszych badań klauzury krzeszowskiej i stanowić dobry punkt wyjściowy do kolejnych analiz przebudowy opactw śląskich.

\section{Conservational works and architectural studies on the enclosure of the old cystercian abbey in Krzeszów that were made since Second World War Summary}

This article is about conservational and study works on the enclosure of an old cystercian abbey in Krzeszów, that were made after the Second World War. Post-war history of conservation of this monument exhibits two periods. The first one covers 50 post-war years, where only routine maintenance was done. The latter period began at the beginning of the XXI century. Since then fragments of the building were renovated piece by piece. Current cultural and touristic needs were taken into consideration.Revalorization of Krzeszów Abbey in years 2007-2008 and since 20I4 revealed the basements and relicts of the groundfloor of the south and west wings of the complex. At the same time the architectural studies were made, resulting in new conclusions of transformations of this building.

Keywords: conservation, research, abbey, Cistercians, Krzeszów

\section{BIBLIOGRAFIA}

Czapliński K. K., Klasztory i opactwa w Polsce, Katowice 2009.

Dziurla H., Die Grüssauer Klosterkirche und das Piastenmausoleum - Zur Baumeister frage, „Zeitschrift des Deutschen Vereins für Kunstwissenschaft“, 1974, t. 27, z. I/4, s. 54-82.

36 A. Baran, Krzeszów, klasztor - pogmatwane dzieje, op. cit.

37 B. Skoczylas-Stadnik, Skarby lwowskie w Opactwie Benedyktynek w Krzeszowie, Kamienna Góra 2017.

38 R. Werszler, Architektura wnętrza ..., op. cit. 
Dziurla H., Dzieje Krzeszowa, w: H. Dziurla, I. Kořán, J. Wrabec, Krzeszów, europejska perła baroku (Grüssau, die europäische Barockperle), red. A. Jarosiewicz, B. Skoczylas-Stadnik, Legnica 200I, s. 8-I7.

Dziurla H., Krzeszów, Wrocław-Warszawa-Kraków 1964.

Dziurla H., Krzeszów. Studium historyczno-architektoniczne, Wrocław I96I (mps, Regionalny Ośrodek Dokumentacji Zabytków we Wrocławiu - dalej RODZW).

Dziurla H., Studium historyczno-architektoniczne zespołu pocysterskiego w Henrykowie, Wrocław 1965 (mps, RODZW).

Dziurla H., Wertykalizm i tożsamość barokowej architektury Krzeszowa, w: Krzeszów uświęcony łaska, red. H. Dziurla, K. Bobowski, Wrocław I997, s. 236-257.

Baran A., Krzeszów, klasztor - pogmatwane dzieje,, http://szpakowedrzewo.blogspot. com/20I4/oI/pogmatwane-dzieje.html (dostęp: I0.07.20I8).

Kalinowski K., Architektura doby baroku na Śląsku, Warszawa 1977.

Kapałczyński W., Prace remontowo-konserwatorskie w okresie powojennym. Stan obecny zabytków zespołu w Krzeszowie, w: Krzeszów uświęcony łaską, red. H. Dziurla, K. Bobowski, Wrocław 1997, s. 360-375.

Kompleksowa opinia mykologiczno-budowlana. Rozpoznanie wstepne agresji biotycznej, opr. B. Kuzynków, PP PKZ i977, Wojewódzki Urząd Ochrony Zabytków, dalej: WUOZ, sygn. nr A/A-653.

Konstrukcja. Wstępna opinia o stanie technicznym obiektów położonych w Krzeszowie, opr. St. Wojdon, PP PKZ 1977 (mps, WUOZ), sygn. nr A/A-654.

Kosztorys. Klasztor, opr. M. Majka, PP PKZ 1969, WUOZ, sygn. A-663.

Kuthan J., Počátky a rozmach gotické architektury v Čechach, Praha 1983.

Kutzner M., Cysterska architektura na Śląsku w latach I200-I330, Toruń I969.

Kutzner M., Średniowieczna architektura klasztoru cysterskiego w Krzeszowie, w: Krzeszów uświęcony łaska, red. H. Dziurla, K. Bobowski, Wrocław I997, s. I32-I40.

Łużyniecka E., Architektura klasztorów cysterskich. Filie lubiąskie i inne cenobia śląskie (The architecture of Cistercian monasteries. Daughter houses of Lubiaż and other Silesian cenobia), Wrocław 2002.

Łużyniecka E., Architektura średniowiecznych klasztorów cysterskich filiacji lubiąskiej, Wrocław 1995.

Łużyniecka E., Pelplin i Doberan. Architektura opactw cysterskich spokrewnionych filiacyjnie, Wrocław 20I4, s. 794-802.

Łużyniecka E., Średniowieczny klasztor cysterski w Krzeszowie na podstawie ostatnich badań architektonicznych, „Architektura. Czasopismo Techniczne”, 7-A/20II, z. 23, R. I08, s. 44I-460.

Małachowicz E., Wczesnośredniowieczna architektura kościoła dominikanów we Wrocławiu, „Kwartalnik Architektury i Urbanistyki”, 1975, t. 20, z. I, S. II-50.

Monasticon Cisterciense Poloniae, red. A. M. Wyrwa, J. Strzelczyk, K. Kaczmarek, Poznań I999.

Pilch J., Leksykon zabytków Dolnego Śląska, Warszawa 2005.

Prace konserwatorskie na terenie województwa dolnośląskiego w latach 1979-I999, red. G. Grajewski, E. Kica, Wojewódzki Urząd Ochrony Zabytków we Wrocławiu, Wrocław 2005 . 
Prace konserwatorskie na terenie województw jeleniogórskiego, legnickiego, wałbrzyskiego, wrocławskiego w latach I974-I978, opr. K. Bartnik et. al., kons. meryt. E. Lenkow, BSiDZ, wyd. Zakład Narodowy im. Ossolińskich, Wrocław-Warszawa-Kraków-Gdańsk-Łódź 1985 .

Prace konserwatorskie na terenie województwa wrocławskiego w latach I969-I973, opr. R. Motyl, B. Uszałowicz-Piąty, J. Skibińska, Biuro Studiów i Dokumentacji Zabytków, Narodowy Zakład Imienia Ossolińskich, Wrocław-Warszawa-Kraków-Gdańsk 1976.

Projekt budowlany zmiany remontu klasztoru w zespole pocysterskim w Krzeszowie. Architektura i konstrukcja, opr. A. Baran, Świdnica 2008, WUOZ, sygn. nr A-I4/382.

Projekt techniczny remontu klasztoru $w$ Zespole pocysterskim $w$ Krzeszowie. Architektura i konstrukcja. Budynek klasztorny, proj. A. Baran, Świdnica 2005, WUOZ, sygn. nr A-29/94.

Rewaloryzacja - etap II, http://www.opactwo.eu/index.php/co-nas-czeka-2/I8-sanktuarium-matki-boej-askawej/ue/I28-rewaloryzacja-etap-ii (dostęp: I0.07.20I8).

Sierpowska-Kaczmarek M., Południowo-zachodni Szlak Cysterski. Założenia i realizacja nowego produktu turystycznego, w: Przyszłość badań nad historia i kultura cysterska w Polsce, red. E. Łużyniecka, A. Galar, Wrocław 20II, s. 243-256.

Skoczylas-Stadnik B., Skarby lwowskie w Opactwie Benedyktynek w Krzeszowie, Kamienna Góra 2017.

Sołdek R. M., Szlak cysterski na Dolnym Śląsku, Wrocław 2007.

Untermann M., Forma Ordinis. Die mittelalterliche Baukunst der Zisterzienser, Berlin $200 \mathrm{I}$.

Werszler R., Architektura wnętrza i umeblowanie biblioteki opactwa cystersów w Krzeszowie $w$ świetle badań historycznych, „PERSPECTIVA Legnickie Studia Teologiczno-Historyczne", R. 8, 2009, nr I (I4), s. 229-252.

Wrocławski T., Sprawozdanie z nadzoru archeologicznego prowadzonego $w$ wirydarzu klasztoru w Krzeszowie, 2000 (mps, WUOZ).

Wyrwa A. M., O możliwościach datowania zapraw metoda I4C w obiektach architektonicznych, „Wielkopolski Biuletyn Konserwatorski”, I/2002, s. I69-I8I.

Zabytki sztuki w Polsce. Śląsk, red. S. Brzezicki, Ch. Nielsen, G. Grajewski, D. Popp, Warszawa 2006.

Zespół zabytkowy w Krzeszowie. Studium organizacji i realizacji prac konserwatorskich, opr. A. Wolski, Przedsiębiorstwo Państwowe Pracownie Konserwacji Zabytków Wrocław 1978 (mps, Archiwum Wojewódzkiego Urzędu Ochrony Zabytków w Jeleniej Górze), nr A-66I, notatka z 2004 r. niechronologicznie włączona do zespołu akt.

Ziętara B. i in. Krzeszów uświęcony łaska, Wrocław 1997. 